seems equally unjustified, since, while the stabilising effect of parasites' responses to patchiness in host density would be removed, the major cause of instability-differences from year to year in the relative timing of egg hatch and bud burst--would, in the authors' interpretation, also be reduced.

M. C. Singer

\section{Obedient unto death}

Obedience to Authority: An Experimental View. By Stanley Milgram. Pp. xvi +224. (Tavistock: London; May 1974.) £2.50.

"I was just obeying orders". From My Lai to Auschwitz and doubtless back to the time of Genghis Khan and before, the perpetrators of atrocities have excused their actions with some variation on that theme. Many people dismiss that excuse; they feel that the people involved in such horrors must be sadistic brutes not typical of the human race and comfort themselves with the secure knowledge that they would have the will and strength to refuse to obey such orders. Those comforting beliefs are shattered by Professor Milgram's account of his experiments at Yale during the 1960s. In the tests, subjects recruited from the general public to take part in what they believed to be a learning experiment were placed in a situation where they were required, under the orders of the "experimenter", to administer severe electric shocks to someone they thought to be another unsuspecting recruit for the learning experiment. Their willingness to do so is astonishing, and provides a new basis for understanding, if not excusing, the behaviour of people "just obeying orders".

Most of this book is taken up with descriptions of the various forms of the experiment and the responses of the subjects. Put baldly, it seems astonishing that anyone participated at all. Each volunteer was paired with an actor who was to be the victim in the experiment, and a rigged lottery ensured that the subject became the "teacher". The rationale of the test, as explained to him, was that the "learner" was to be encouraged to remember word pairs in a list by administration of electric shocks of increasing severity every time he made an error. The teacher had to administer these shocks while the genuine experimenter acted as the voice of authority. Many people were quite happy to administer what they genuinely believed to be shocks of up to 450 volts, while the learner screamed, protested, demanded to be released from the experiment and finally fainted.

Even when the teacher protested to the experimenter about the situation,

\title{
Fate, time, occasion, chance and change
}

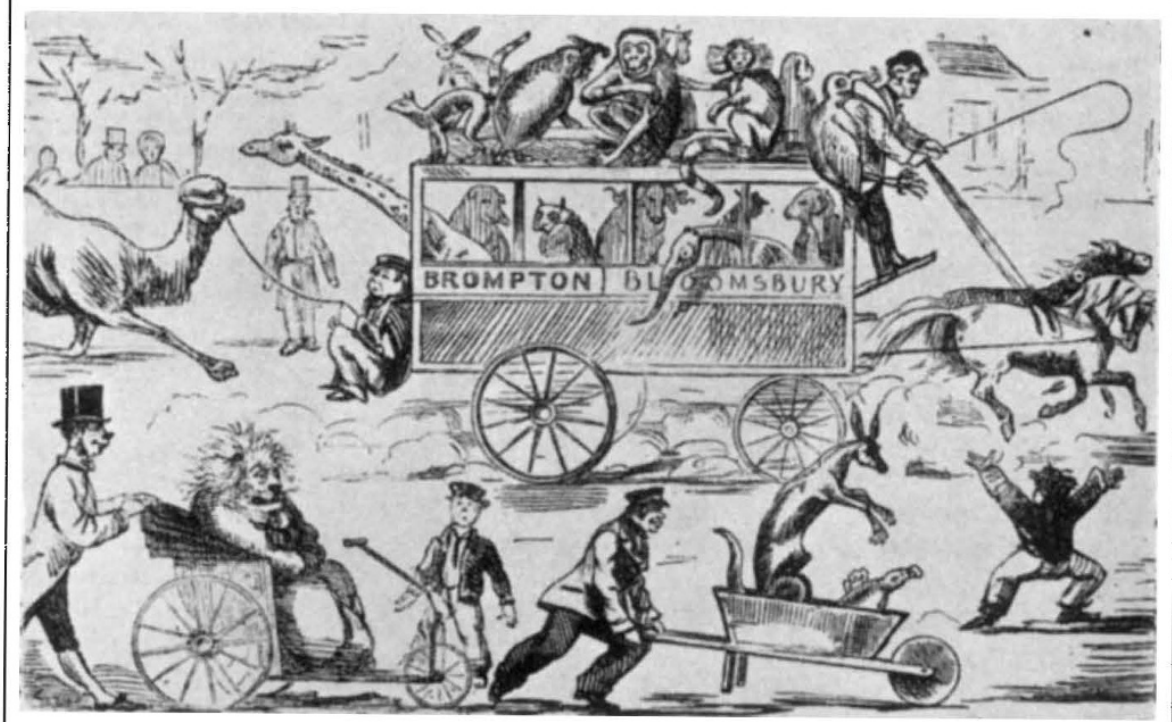

Cartoon in The Comic Muse, July 18 1863, of the proposed removal of the Natural History collections to South Kensington (in fact not moved until the 1880s).

IT hasn't always been 'all change' at the British Museum, but as readers of Edward Miller's scholarly and readable history (That Noble Cabinet, Deutsch, London, February $1974 ; £ 4.80$ ) of the museum will soon discover, this famous institution has not been blessed with a particularly peaceful existence. For the first 150 years of the museum's life, since its foundation by Act of Parliament in 1753 , if there weren't squabbles between the government, the trustees and the staff about money and buildings, there were worries about staffing, space and facilities; and in Victorian times especially there also seem to have been endless bickerings between certain of the senior staff.

The museum, however, weathered all the storms-including a heavy battering during the Second World War-and is all set to face the next

he could usually be encouraged to carry on for some time, administering greater and greater shocks by such responses as "The experiment requires you to continue" or "It is absolutely essential that you continue". The voice of authority carried remarkable weight. So much so that the early simple versions of the experiment proved useless in defining exactly where people would draw the line. From having the 'victim' out of sight in the next room, successive modifications of the experiment eventually lead to physical contact, when the teacher had to hold the protesting learner in con- upheavals when, if present plans materialise, the library will be severed from the other departments and uprooted into new buildings. The museum was founded mainly as a department of natural history; ironically, it was this departmentdespised by the great librarian Panizzi (the architect of the present reading room)-which was the first major section to be severed physically if not completely emotionally from Bloomsbury when it was moved in the 1880 s to Waterhouse's new buildings in South Kensington.

Miller-himself a museum man -has written a fascinating tale. There is no doubt that the BM has been favoured with more good luck, and loyalty from benefactors and staff, than its trustees and the British nation have at times deserved.

Sarah Bunney

tact with the plate supposedly giving shocks. And some people, acting under orders, carried out their duties up to the 450 volt level clearly labelled with "Danger Severe Shock". It is natural to ask how careful the experimenters were in their investigationcan their results be extrapolated to normal conditions? The answer seems to be yes. Over several years variations on the experiment were tried in which the "authority" was no longer respectable Yale University but a seedy (and fictitious) firm of "Research Associates", operating from a run down neighbourhood. Various permutations 